\title{
How Much and to Whom Does Free Education Cost? Human Right Based on Solidarity
}

\author{
Gabriele Taminskaite \\ Vilnius University Faculty of Law / University Paris Nanterre
}

\begin{abstract}
According to international and European Union legislation, everyone has equal rights to education at all levels, and the access to compulsory education must be free of charges for all. The commonly used wording of "free education" leads to a widespread perception in society that education, often not only compulsory but also university education, costs nothing to anyone. The article raises the question of whether education is really free. It discusses in the legal context who actually funds education and on what basis. The article looks for the answers to the questions, what does public solidarity idea mean, what is the balance between legitimate interests of a person and the needs of the society and the state, what is the purpose of it and how to guarantee it.
\end{abstract}

Keywords: principle of solidarity, right to education, free education

\section{Introduction}

Learning is the natural right of every person. Law of the European Union (hereinafter referred to as the $\mathrm{EU}$ ) and international legislation guarantee to everyone the right to free compulsory education as well as the right to vocational and continuing training. Member states of the European Union, while regulating the area of education at the national level, also guarantee these or wider rights to education to residents of their countries. It is understandable that, to ensure and enforce the rights enshrined in the legislation, irrespective of its legal power, national mechanisms must be put in place and appropriate means must be found. To guarantee the right to education free of charge various legal and economic instruments are invoked. In the context of this article, "free" is one of the key words in the term "the right to free education". The state is obliged has the duty to guarantee "free" education and, thus, it has to find ways to finance such education. This is done through the state budget: alike in the case of other public services that fall under the prerogative of the state, the state allocates 
appropriate funding to each of its regulated areas through redistribution of funds collected from taxpayers. Therefore, free education at a given moment is paid by all current taxpayers.

What is the basis to oblige them to pay for education services provided at a relevant time to other persons? What does public solidarity idea and intergenerational solidarity mean? What is the balance between legitimate interests of a person and needs of the society and the state; what is it needed for and how to guarantee it? These are the main questions raised in the context of modern legal welfare state answering of which seeks to reveal specificities of operation of the principle of solidarity in the area of education of such a state.

The article is mostly based on legal example of Lithuania, a member state of the European Union, in guaranteeing the right to free education and providing certain broader guarantees related to this right, i.e. guaranteeing free higher education. To answer the questions above, the article uses logical method, systematic analysis and other methods, and is mostly based on the following sources: jurisprudence of the Constitutional Court of the Republic of Lithuania, international and national legislation as well as the one of the European Union, legal doctrine, etc.

\section{From international to national regulation}

Article 14 of the Charter of Fundamental Rights of the European Union enshrines everyone's right to education and to have access to vocational and continuing training. This right includes a possibility to receive free compulsory education. The principle of free compulsory education, without prejudice to operation of certain special forms of education, vocational or continuing training, in particular private ones that are paid, means that every child must have possibility to attend an educational institution free of charge. ${ }^{1}$ Article 2 of the Protocol to the European Convention on Human Rights (hereinafter referred to as ECHR) suggests the following: "No person shall be denied a right to an education. In the exercise of any functions which it assumes in relation to education and to teaching, the State shall respect the right of parents to ensure such education and teaching is in conformity with their own religious and philosophical convictions." Having reviewed other acts of the European Union, such as the European Convention on Human Rights, it is evident that this level enshrines equal rights of all people to education of all stages,

\footnotetext{
${ }^{1}$ See a comment of the European Union Agency for Fundamental Rights regarding provisions of the Charter on the Fundamental Rights of the European Union.
} 
and compulsory, i.e. secondary education, must be accessible free of charge to everyone.

On the one hand, international regulation enshrines cornerstone principles and specifies directions for national legal regulation of the states in the respective areas. On the other hand, a major part of provisions of international law, in particular legislation of the European Union, are based on constitutional traditions common to the member states and cherished and time-tested values. Education in Lithuania, as well as in many other countries, is regulated by special laws ${ }^{1}$ whereof provisions conform to and are formed on the basis of principles enshrined in the basic national law, the Constitution. Three Articles of the Constitution of the Republic of Lithuania (1992) (hereinafter referred to as the Constitution) cover area of education in Lithuania. Within the scope of this investigation, only provisions of Articles 41 and 42 of the Constitution are meaningful, which, inter alia, speak about funding of education and science in Lithuania and its accessibility to all people. Article 42 of the Constitution enshrines freedom of science, research and teaching and support of the state to culture and science. Whereas Article 41 not only provides for compulsory education under the age of 16 but also enshrines that "education at state and municipal schools of general education, vocational schools, and schools of further education shall be free of charge. Higher education shall be accessible to everyone according to their individual abilities. Citizens who are good at their studies shall be guaranteed education at state schools of higher education free of charge." The Constitutional Court of the Republic of Lithuania (hereinafter referred to as the Constitutional Court), in a number of its rulings, provided interpretation of provisions of this article, which enshrine principles of universal equality and differentiation ${ }^{2}$, according to everyone's personal abilities, in seeking education and guarantees free education in the state higher education for persons who are good at their studies. According to the Constitutional Court (2002, case No 25/01), the human right to seek

\footnotetext{
${ }^{1}$ See the Republic of Lithuania Law Amending the Law on Education, the Republic of Lithuania Law on Amendment of the Law on Science and Studies.

2 In its ruling of 14 January 2002, the Constitutional Court of the Republic of Lithuania suggested that the constitutional provision that higher education is available to everyone according to his abilities means that both state and non-state higher schools established according to the procedure prescribed by law, the entire system of higher education establishments, have to be accessible to every person. This provision also means that those who seek higher education cannot be subjected to requirements that are based on criteria other than their abilities. The said provision is closely related to the principle of equality of individuals enshrined in Article 29 of the Constitution, to the provision contained in Paragraph 2 thereof that a person may not have his rights restricted in any way, or be granted any privileges, on the basis of his or her sex, race, nationality, language, origin, social status, religion, convictions, or opinions.
} 
higher education is an important condition for the implementation of one's various rights and legitimate interests. The most important is that the Constitutional Court (2002, case No 25/01) also names that the constitutional right to seek higher education presumes the state's duty to ensure preconditions necessary in order to implement this right. With wider disclosure of the notion "a citizen who demonstrates good academic results" for the first time, the Constitutional Court stated, in its ruling of 14 January 2002, that when a citizen of the Republic of Lithuania demonstrates good academic results in the higher education institution (i.e. his learning meets the established criteria of good academic results), a constitutional obligation arises to the state to cover his tuition (2002, case No 25/01). ${ }^{1}$ According to the Constitutional Court, pursuant to Paragraph 3 of Article 41 of the Constitution, higher education tuition of citizens who are students at state higher schools and demonstrate good academic results cannot be imposed on these persons themselves in whatever form. Higher education of citizens who are students at state higher schools and demonstrate good academic results is financed by the state (2002, case No 25/01). Therefore, free education is understood unambiguously as education financed from the state budget.

\section{Solidarity is the guarantee of free education}

Due to normally used wording "free education" there is a widespread perception in society that education, especially in the general education institutions, is free of charge. It is true that neither the pupils themselves nor their parents or guardians pay tuition fees directly. As mentioned, education services are financed by the state. It is, therefore, wrong to assume that these services are compensated by the state and they are free of charge to the citizens. The state budget consists of the taxpayers' money. In Lithuania, there are over 20 different types of taxes ${ }^{2}$, which are paid by every resident of Lithuania due to their professional and other activities performed daily, assets and under other grounds. Fees paid to the state budget are redistributed to finance relevant areas, in which the state operates, inter alia, education and science. Tax revenue raised to the state budget is used to finance public functions, i.e. areas that fall under prerogatives of the state, because members of the society would not be

\footnotetext{
${ }^{1}$ See Paragraph 3 of Article 41 of the Constitution establishes the right of every citizen with a good academic progress in a state higher school to free higher education. According to interpretation of the Constitutional Court, this right presumes that funds must be provided out of the state budget to guarantee higher education free of charge to citizens who demonstrate good academic progress in state higher schools.

2 See Article 13 of the Constitution of the Republic of Lithuania. Official Gazette, 28-04-2004, No. 632243.
} 
able to take care of them individually for one reason or another ${ }^{1}$. This is a feature of a welfare state. It should be noted that the modern welfare state is understood to be as a state whose law enshrines rights both allowing a member of the society, who is in a certain statutory situation and/or meets certain set requirements, to be qualified for a relevant benefit, allowance or support of another form and to obtain it, and presuming the duty to the state to ensure, through its institutions and public services it provides, an adequate standard of living for persons enabling them to play a full part in social and cultural life and guaranteeing dignified living conditions. In the author's view, it also includes such public services as education. According to the Constitutional Court, Paragraph 3 of Article 41 of the Constitution ${ }^{2}$ should be construed in the context of the striving for an open, just, harmonious civil society and state under the rule of law $^{3}$ as well as public solidarity enshrined in the Preamble of the Constitution. The fact that the tax burden is borne by the whole population, despite the fact that many of them do not personally benefit from education at the given time, nor they used it in the past and will possibly never use it in the future ${ }^{4}$, is based on solidarity inherent to society. It means that a part of the society, which is obliged to pay taxes at the given time, thus finances, inter alia, educational services for those who receive them. According to the author, this is an example of intergenerational solidarity, which in a sense, unlike the case of old-age pensions, is directed more towards the past than the future. How is it understood?

Free education is financed by taxpayers who, in most cases, are adults of working age. It is likely that these individuals have completed not only compulsory education, but also vocational or university education, which was also financed by taxpayers at the given time. Therefore, following the idea of an intergenerational solidarity principle

\footnotetext{
1 With regard to the rules of the free market, and if the state did not take responsibility to care of education, while ensuring access to education for everyone, education, like many other services, would freely circulate in the market, meaning their cost would depend directly on demand and supply, and it would probably become "a commodity" affordable not for everyone. The fact that the state has an interest in constantly maintaining an adequate number of professionals in a particular field and in seeking to have the highest possible qualifications must enable the best students to receive appropriate education free of charge. It is also necessary to provide access to basic education on the basis of education up to 16 years age, which is mandatory for all people, ensuring that this education is free and, therefore, accessible to absolutely everyone.

${ }^{2}$ Higher education shall be accessible to everyone according to individual abilities." Citizens who are good at their studies shall be guaranteed education at state schools of higher education free of charge." ${ }^{3}$ See the Constitution of the Republic of Lithuania. Official Gazette, 1992, No. 33-1014 (30.11.1992).

${ }^{4}$ It can be explained by various reasons, e.g. people choose private education and pay directly for their education and training, so they never take advantage of free education, guaranteed by the state and financed from its budget.
} 
applied to old-age pensions, whereby the taxes paid by employees at the given time are allocated to the then old-age pensioners, on the basis that in future the taxpayers (in particular members of the social insurance system) at their respective age and conforming to other criteria, will get entitled to the old-age pension benefit, in case of free education, prospective taxpayers benefit, first of all, from funding to obtain education and only then cover indirectly their costs by financing education services for younger generations. Thus, in this case, intergenerational solidarity operates rather retrospectively than prospectively. The author points out that, by the given example, there is no attempt to compare the operation of the principle of solidarity with regard to old-age pensions and that of free education. These are two different areas within the prerogative of the state, which are subject to both different legal regulation and the means of its implementation and enforcement: the old-age pension, unlike education, is financed by social insurance. The example of operation of the principle of intergenerational solidarity in the area of old-age pensions is purposed to disclose direction of operation and aims of this principle in the event of free education. Therefore, the state, through its prerogative and redistribution of funds, finances education area jointly and severally with money of all taxpayers to everyone who is entitled to free compulsory education and pursues to exercise this right, and in the event of free higher education also meets other requirements.

Another distinguishing feature of the principle of intergenerational solidarity in the education area is that its operation is directed towards future, but with a purpose other than that of old-age pensions. The availability of higher education to everyone according to their individual abilities and guarantee of education free of charge in the state establishments of higher education to citizens who demonstrate good academic results are both aimed at ensuring the common interest of these persons, the society and the state, which are in a need for specialists with higher education in different areas (2002, case No 25/01). Prof. Dennis Farrington holds critical position on selection of students to higher education institutions in the young member states of the European Union, following preparation of a future workforce known as statecommissioned specialist recruitment. According to the Professor, it leads to overregulated and restricted curriculum content (Farrington, D.; Palfreyman, D. 2016). In his view, free studies should be provided based on the financial need of each individual but not on the need of the state to have a certain number of professionals. However, the author follows the position of the Constitutional Court of Lithuania as, according to her opinion, enforcement of the right to free education is also guarantees of welfare of the whole society. Therefore, an idea can be developed that every 
individual as a part of society has a duty to contribute in part to ensuring this welfare of society, and this duty must be in harmony with justice, another principle of the welfare state. Meanwhile, justice of the state's investment in selected candidates, when their tuition fees are to be borne by all taxpayers, is questioned by Prof. Milton Friedman, one of the most prominent economists in America. According to him, such redistribution of income by the state is arbitrary and unjust: "If subsidies were given to anyone seeking education and meeting minimum qualification requirements, there would be an overinvestment in people. <...> To prevent such overinvestment, the state must restrict subsidies. Not to mention the fact that it would be difficult to calculate a "fair" amount of investment, and it would require in principle arbitrary selection of investment candidates. The lucky ones, whose education would be subsidized, would receive all the income from such investments, while all their costs should be borne by ordinary taxpayers, with a completely arbitrary and almost certainly unfair redistribution of income. The aim should be not to redistribute income but to make almost equal opportunities for investment to both human and physical capital“ (Friedman, M., 2010). Therefore, this author tends to highlight almost equal opportunities for investment into human capital ensuring equal access to higher education, i.e. to make opportunities for individuals for their free studies and later, at the respective period, to cover their education-related costs.

\section{The balance between the individual and the public interests}

It is worth mentioning interpretation of the Constitutional Court, according to which one of the main objectives of law as means to regulate social life is justice, which is one of basic moral values, as well as that of basic foundations of state governed by law. The aspiration after justice and state governed by law is established in the preamble of the Constitution and, according to the Constitutional Court, may be implemented by ensuring a certain equilibrium of interests, by escaping fortuity and self-will, instability of social life and conflict of interests (1995, case No. 9/95). It is impossible to attain justice by recognising the interests of only one group or one person and by denying the interests of others at the same time (1998, case No. 15/97). Therefore, members of society, on the one hand, having guarantees provided by the welfare state and being able not only exercise their own rights but also benefit from a wide range of professional and other opportunities based on these rights, with the help of society of solidarity, on the other hand, are obliged to contribute to this common system which makes opportunities to meet interests of both separate individuals and the whole society, which, inter alia, guarantee advancement in science, technology and other fields and proper functioning of the state. Without any 
doubts, the measures (in this case, funding of education from the state budget) necessary to pursue interests of some individuals (seeking free higher education) cannot be applied to such an extent and in such a way as to deny rights and interests of other people (rights and interests of taxpayers, who contribute to funding of education, and certain recipients of benefits from the state budget, to whom amount of the benefits is determined according to financial capacity of the state). In most cases imbalance in any area is not considered as a positive condition. Areas of the public policy, finance and law, which are related to the discussed subject, are not an exception. Therefore, it may be argued that a balance must be struck between legitimate interests of an individual and needs of society and the state. In support of this idea, the Constitutional Court develops it in terms of limits of guarantees provided to the state people in enforcing their respective rights. In the ruling of 14 January 2002 , it noted that the financial possibilities of the state (including the possibilities of funding higher education) are not and cannot be unlimited. The constitutional provisions that higher education shall be available to everyone according to their individual abilities cannot be interpreted as imposing a duty on the state to ensure the funding of any higher education for anyone capable of seeking it without proper consideration of the needs and possibilities of the society and the state (2002, case No. 25/01). As already mentioned, there has to be a balance between the legitimate interests of a person and the needs of both the society and the state, and the financial possibilities of the state (including the possibilities of funding higher education) are limited (2002, case No. 25/01). The law may not establish any such model of financing higher education, which would not be based upon a balanced assessment of the needs of society and the state and the financial capabilities of the state, where the state would clearly be unable to implement such model; the establishment of such model would be in conflict, inter alia, with the constitutional imperative of social harmony and would not allow the state to perform its various other obligations (2008, case No. 28/07-28/29). Therefore, the state is obliged to provide access to free higher education, but only having objective possibilities and only to the extent that funding of higher education would not violate rights of other individuals, i.e. the principle of justice and proportionality in relation to taxpayers and other recipients of state benefits would not be violated, which would mean violation of interests of not only individuals but also of the society as a whole.

In the opinion of the Constitutional Court, the same provision that the higher education is accessible to everyone according to the abilities of every person may not be construed as denying the constitutional right of a person to pursue the higher 
education according to his abilities, even if it is not funded by the state due to the reason that it exceeds the needs and capacity of the society and the state (2002, case No.25/01). Therefore, in accordance with the Constitutional Court, this means that the need of the society and the state to have specialists of various fields with the higher education and the possibility to finance education of only a particular number of specialists required by the state at the relevant time cannot be an obstacle to a person to pursue the higher education out of the state funds also when it goes beyond capabilities of the society and the state. Thus, an opportunity to obtain a desired education through private funding is not only open to a limited number of the best learners, so ensuring the constitutional right of every person to pursue the higher education. In this context, it should be noted that the Constitution does not prohibit the state, in the more favourable economic situation according to its possibilities, from incurring higher financial obligations to students of higher education institutions than it follows from the constitutional provision that education free of charge is guaranteed to the citizens who are good at their studies; however, in this case, in accordance with the interpretation of the Constitutional Court, the pursuit of a just and harmonious society, enshrined in the Constitution, must not be denied (2002, case No.25/01; 2011, case No. 13/2010-140/2010). Therefore, in Lithuania, as in many other European countries, with regard to the fact that all members of society share jointly the burden of funding, while grounding education by common interest of the society, without prejudice to the principle of justice stemming from the rule of law, the right to free education is provided, first of all, to such number of specialists that complies with needs in the society and the state at the given time. Secondly, only the studies of the very best and potentially the most qualified future professionals are financed. In the author's view, this reflects an attempt to balance the constitutional principles of solidarity, justice and proportionality. Therefore, the state having the duty to finance higher education and ensuring balance of rights and interests of all members of the society and overall welfare of the society guarantees free education in the state higher education institutions to the citizens who study under order of the state while meeting its established need of specialists in the respective areas (directions) provided that their studies comply with statutory criteria of good academic results and within financial possibilities of the state.

\section{Conclusions}

It is derived from the Constitution that higher education of citizens who are students at state higher schools and demonstrate good academic results is financed by the state as the constitutional right to seek higher education determines the state's duty to 
ensure preconditions necessary in order to implement this right. Like other public services, education is financed by the state on the basis of the principle of solidarity inherent to welfare states.

Public solidarity is based on the fact that every individual as a part of society has a duty to contribute in part to ensuring this welfare of society. Members of society, on the one hand, having guarantees provided by the welfare state and being able not only exercise their own rights but also benefit from a wide range of professional and other opportunities based on these rights, with the help of society of solidarity, on the other hand, are obliged to contribute to this common system which makes opportunities to meet interests of both separate individuals and the whole society, which, inter alia, guarantee advancement in science, technology and other fields and proper functioning of the state.

Intergenerational solidarity is usually about features operation towards future, but solidarity in education has also retrospective nature. It manifests by the fact that guaranteeing free education to citizens who demonstrate good academic results are both aimed at ensuring the common interest of these persons, the society and the state, which are in need for specialists with higher education in different areas, but also future taxpayers in the state, first of all, benefit from funding to receive education and only then indirectly bear its cost by financing education services for younger generations.

The state is obliged to provide access to free higher education, but only having objective possibilities and only to the extent that funding of higher education would not violate rights of other individuals, i.e. the principle of justice and proportionality in relation to taxpayers and other recipients of state benefits would not be violated, which would mean violation of interests of not only individuals but also of the society as a whole.

\section{Reference}

[1] 14-01-2002 ruling of the Constitutional Court of the Republic of Lithuania, case No. 25/01.

[2] 20-03-2008 ruling of the Constitutional Court of the Republic of Lithuania, case No. 28/07-29/07.

[3] 22-12-1995 ruling of the Constitutional Court of the Republic of Lithuania, case No. 9/95.

[4] 22-12-2011 ruling of the Constitutional Court of the Republic of Lithuania, case No. 13/2010-140/2010. 
[5] 27-10-1998 ruling of the Constitutional Court of the Republic of Lithuania, No. $15 / 97$.

[6] A comment of the European Union Agency for Fundamental Rights regarding provisions of the Charter on the Fundamental Rights of the European Union. Viewed on 02.02.2020, link online: https://fra.europa.eu/en/eucharter/title/title-ii-freedoms.

[7] Dennis Farrington, David Palfreyman. The Law Of Higher Education. Oxford, 2016.

[8] Milton Friedman. CAPITALISME ET LIBERTÉ. LEDUC.S Éditions, 2010.

[9] Republic of Lithuania Law Amending the Law on Education. Official Gazette, 31-03-2011, No. 38-1804.

[10] Republic of Lithuania Law on Tax Administration. Official Gazette, 28-042004, No. 63-2243.

[11] The Charter on the Fundamental Rights of the European Union.

[12] The Constitution of the Republic of Lithuania. Official Gazette, 1992, No. 331014 (30-11-1992).

[13] The European Convention on Human Rights.

[14] The Republic of Lithuania Law on Amendment of the Law on Science and Studies No. XI-242. TAR (Register of legal acts), 14-07-2016, No. 20555. 